\title{
Errors Analysis of Spelling Among University Students of English in Jordan: An Analytical Study
}

\author{
Jibrel H. Al-Saudi ${ }^{1}$ \\ ${ }^{1}$ English Language Department, Faculty of Arts and Sciences, The World Islamic Sciences \& Education \\ University, Amman, Jordan \\ Correspondence: Jibrel H. Al-Saudi. E-mail: jibrelsaudi@yahoo.com
}

Received: June 18, 2020

Accepted: June 30, $2020 \quad$ Online Published: November 30, 2020

doi:10.5539/ass.v16n12p19

URL: https://doi.org/10.5539/ass.v16n12p19

\begin{abstract}
This paper aims at investigating the spelling mistakes made by students of English language in The World Islamic Sciences and Education University (WISE) in Jordan. The researcher adopted Cook's classification of errors in this study. Students mistakes were categorized into four classifications: substitution, omission, insertion, and transposition. Fifty students were participated in the study by enrolling in the "Error Analysis" course in two semesters of the academic year 2016/2017. The data for the study were derived from three exams: the first, the second, and the final exams, given to the students during the two semesters. Then the data were analyzed after completing the course in the second semester of 2016-2017. The results of the study revealed that (38\%) of the errors referred to omission and (28\%) to insertion. However, the study showed that (22\%) of errors referred to substitution, while only (15\%) of them referred to transposition. This study showed that using vowels and pronunciation incorrectly is one of the major causes of the learners' errors. Further, the interference of the first language plays a significant role in this regard. The study concludes that more efforts and concern should be given to spelling errors made by students since the learning of spelling is an integral part of language learning. The researcher suggested some recommendations and pedagogical implications to be studied in the future.
\end{abstract}

Keywords: spelling mistakes, omission errors, substitution errors, transposition errors, insertion errors

\section{Introduction}

Language is an audible behavior through which people can express and communicate their thoughts, feelings, and attitudes. Learning a second language has always been everyone's dream. However, it is challenging to learn a new language. There appear some problems encountered by EFL students when learning a language. Spelling is one of the biggest problems that many EFL students face in writing English. Fagerberg, (2006) claims that spelling is so necessary that one misspelling may lead to a change in meaning to be conveyed in a text. According to Cook (1999), spelling mistake is one of the most challenging problems in learning English writing skills. However, AbiSamra (2003) points out that mistakes are valuable and resourceful information in the strategies of learning. Such mistakes are regarded as stratagem, which can gain an advantage in the learning process. Moreover, they allow for evidence of the level of the learners in the target language (Gass \& Selinker, 1984).

English spelling and phonological rules are reciprocally connected. Such an interconnection contributes to mainly make spelling mistakes. This interdependence between English spelling and phonological rules complicates spelling rules associated with difficulty and irregularity (Al-Saudi, 2013). According to Altamimi and Rashid (2019), errors are often made by the learners, who are most familiar with words of specific written forms; therefore, differences between spelling and pronunciation in many languages pose a significant challenge to inexperienced learners of English. That is to say, a word or a morph will be pronounced by students according to its orthography, provided that its pronunciation might be different from its spelling. Besides, interpreting some combinations of letters according to the rules of spelling of another language would be another common mistake (Wachowicz \& Scott, 1999).

Hildreth (1962) pointed out that the evidence of good manners is the correct spelling, while weak spelling implies insufficient education or lack of care. However, EFL learners encountered spelling problem for not being able to identify pronunciation distinctly, which is a severe problem affecting students to make mistakes, particularly with the use of the vowel sounds and other consonant sounds that do not have direct equivalents in 
their native language e.g., /p/ /b/, /f/ and /v/. For example, Al-Saudi, (2013) reported that students in Jordan, whose native language is Arabic, often make mistakes when they inscribe the /p/ sound and the silent /e/ at the end of a word; subsequently, /p/ becomes /b/ or vice versa as in: (put-but), (example- exambel), and (have-hav).

The educational system in Jordan requires that the four skills of the English language, which are reading, listening, speaking and writing, be mastered by the students. Analyzing spelling mistakes made by students provides a deep understanding of the learning process. Error analysis is significant in diagnosing the difficulties experienced by students, so that such spelling problems made by students can be facilitated and solved, which will help improve students' ability in writing, transforming them into good spellers. Many studies, which focused on students' spelling mistakes, have been reviewed, particularly in Jordan. Only few studies conducted were found to discuss the difficulties in spelling faced by students majoring in English language at Jordanian universities. These studies have discussed such matters as sources of mistakes, mistakes in grammar, and mistakes in spelling, which are based on pronunciation among students learning English.

One of these studies was conducted by Al-Zuoud (2013), who investigated common mistakes made by Jordanian students learning English in a written composition, classifying students' spelling mistakes following the error classification of Cook. More studies are reviewed in the literature review section. Cook (1999) categorized mistakes into four categories: substitution mistakes, where students substitute a letter with another one, omission mistakes, which means the omission of a letter in the target word, insertion mistakes, where the students add a letter to the target word, and transposition mistakes that take place when the order of two letters or more in a word is reversed by the students.

Therefore, the present study aims to examine the spelling mistakes made by university students, who major in English, and to investigate the difficulties, trying to identify them and so could be treated effectively. The study also provides suggestions that can improve the spelling skills of the students. Besides, the current study establishes error analysis as a way to reveal the origins of spelling mistakes and the reasons behind their frequent occurrence. Accordingly, determining the remedy might be possible, provided that the sources and reasons had been brought out.

\subsection{Objectives of the Study}

The objectives of the study are as follows:

- To examine the reasons behind making spelling mistakes made by university students.

- To classify and analyze the different types of mistakes in spelling and, which create spelling problems faced by the students of English at WISE mistakes University.

- To identify the learning strategies in order to provide the solution for spelling mistakes made by the students.

\subsection{Research Questions}

This paper mainly focuses on analyzing the WISE University students' mistakes in spelling of English. The study also gives answers to these questions:

- What are the categories and potential sources of the mistakes Jordanian university students make in spelling?

- What causes the typical mistakes in the spelling made by Jordanian university students in writing skills?

- What techniques should be applied in order to overcome the spelling problems of students?

\subsection{Literature Review}

This section reviews the literature related to spelling mistakes made by students of English language studying at universities. There is a plethora of studies that have investigated spelling difficulties among Arab EFL students when learning the language. One of these studies is conducted by Othman (2018), who investigated spelling mistakes made by the Saudi students at English Department at the University of Tabuk in Saudi Arabia. The study revealed that the major cause of spelling mistakes is because of the incorrect use of the vowels and their pronunciation as well as the interference of the first language. The study concludes that more concern should be given to spelling mistakes made by the learners. Therefore, it is very important to teach spelling rules and the relationship with pronunciation in learning English language.

AlBalawi (2017) investigated spelling errors of the introductory year students at the University of Tabuk in Saudi Arabia. The study concluded that there was an impact on the coherence of students' writings, which involved errors classified into three major classifications. These classifications include omission, addition and substitution. 
The study also revealed that the interference of the first language led to the students' spelling mistakes, as it is relevant to the different systems of the foreign language and mother tongue.

Further, another study conducted by Hamed (2016), who investigated and analyzed spelling errors made by Saudi students in English writing skill. The data were collected from 26 Saudi university students by using dictation consisting of fifty words. The study indicated that most errors concentrated on errors in vowels, diphthongs and words with silent letters. Besides, learners applied their knowledge of mother tongue on their English learning experience. The study concluded that substitution was the error category made by the majority of the students, then omission followed by transposition, and finally insertion. Alhaisoni et al. (2015) analyzed the different types of spelling errors "in English composition on 122 EFL undergraduate students at the University of Hail in Saudi Arabia". The researchers collected the data through examining the writing composition of (122) male and female students in their first year. It was found out that most errors were made by students in omission, which is considered the highest among them. The study also showed that the majority of errors were made by the wrong use of vowels and pronunciation. The study concluded that spelling errors occur as a result of the irregularities that exist in English language in addition to the effect of the first language.

Moreover, Benyo (2014), examined errors in spelling made by students studying English language at Dongola University in Sudan. Pretest and posttest on spelling were administered and distributed to (200) EFL students at two faculties in the university. The findings of the study revealed that English vowels and consonants, which do not exist in Arabic language, were the real problem for the Sudanese students in spelling. The study also concluded that another primary cause of students' errors in spelling is attributed to the students' unfamiliarity with and overgeneralization of spelling rules in English. Al-Saudi (2013) investigated the problems in English spelling encountered by the students of English language at Tafilah Technical University (TTU) in Jordan. The objective of the study was to identify different kinds of spelling errors and mistakes made by students in writing English. It also sought the spelling difficulties faced by the students in writing English. The study concluded most mistakes were due to the confusing of spelling rules in English and the irregularities found in spelling and pronunciation in English.

In addition, Al-Zuoud and Kabilan (2013) investigated common mistakes made by Jordanian students learning English in a written composition, classifying spelling errors of students in agreement with the classification of errors stated by Cook (1999). It was found out that the patterns of substitution and omission errors had recorded the highest spelling error occurrence. To improve students' ability in spelling, some strategies were recommended such as more spelling practices should be performed in order to better understand students' problems in spelling. Al-Harrasi (2012) conducted a study at a female school in Oman. The study aimed at exploring the most typical mistakes in English spelling among Omani female students by using a dictation test, which is based on words of one syllable and words of multi-syllable. The data were analyzed according to Cook's classification (1999). The results of the study indicated that substitution was the most common pattern of spelling mistakes, which was a result that is in agreement with earlier studies.

All the above-cited studies are relevant to the present study attempting to conduct similar objectives in investigating the Arab EFL students' spelling errors when learning English. However, this study is different from the studies mentioned above. It intends to examine the most typical spelling mistakes made by EFL students majoring in English Language conducted at the department of English at the World Islamic Sciences and Education University (WISE) in Jordan.

\section{Methodology}

The participants of this study consist of (50) students studying English language at the World Islamic Sciences and Education University (WISE) in Jordan. Those students were selected after they had registered an English requirement Course, entitled (Error Analysis) in two semesters of the academic year 2016/2017. In the first semester, the students, who participated in the Course, were (27). In the second semester, only (23) students participated in the Course. Those students have the same social and educational backgrounds; they are all Jordanian and almost have the same level in English language skills.

\subsection{Instruments of the Study}

The data for the study were derived from three exams: the first, the second, and the final exams, given to the students during the two semesters. The data were collected through reviewing students' answer sheets on the three exams given to them during the semesters. The questions of the tests were based on spelling and grammatical mistakes. Only spelling mistakes were considered and reviewed for the purpose of this study. Then the data were analyzed after completing the course in the second semester of the year 2016-2017. 


\subsection{Data Analysis}

The analysis of the data in this study was based on Cook's (1999) classification of spelling mistakes, which includes omission, substitution, insertion, and transposition. Therefore, measuring reliability for this instrument was not needed as it was developed by Cook in 1999. The researcher analyzed and categorized the data by reviewing all the mistakes made by students and manually classifying the students' answers according to the categories mentioned above. The mistakes were measured and recorded as percentages. Such mistakes were also discussed with the students, so that they could benefit from and avoid making them again.

\section{Results of the Study}

This section reveals the findings of the study and the analysis of spelling mistake made by 50 students studying English at WISE. All four types of mistakes (omission, substitution, insertion, and transposition) were examined independently. The primary sources of mistake were also identified. The analysis of the study is based on Cook's classification (1999), through examining spelling mistakes made by students. Mistakes in spelling were classified based on the types of mistake, which are Omission, Substitution, Insertion, and Transposition (OSIT), as shown in Table 1 below:

Table 1. Frequency of Errors according to Cook's OSIT

\begin{tabular}{ccc}
\hline Type of Mistake & Frequency & Percentage \\
Omission & 42 & $38 \%$ \\
Insertion & 31 & $28 \%$ \\
Substitution & 22 & $19 \%$ \\
Transposition & 15 & $15 \%$ \\
Total & 110 & $100 \%$ \\
\hline
\end{tabular}

Table 1 shows the number of the students who made a diversity of mistake in spelling. The table indicates clearly that the total of mistake made by the English language students at WISE was 110. These mistakes were classified according to the type the mistake. It was found that omission presents the highest error percentage of $38 \%$ (42 mistakes). Next comes insertion type of mistakes with $28 \%$ (31 mistakes), then the mistakes of substitution come after with $19 \%$ (22 mistakes), and then mistakes of transposition with a percentage of $15 \%$ (15 mistakes). However, the study revealed that transposition mistakes and substitution mistakes did not happen as frequently as the first two types of mistakes. The results show that the omission type of mistakes presents the highest score among other styles.

For example, Table 1 shows that examining the typical pattern of mistakes committed by university students in spelling was omission (38\%) such as befor for before or wich instead of which. The second type of mistakes made by them was 'insertion' ( $28 \%$ ), such as withe for with or knowen for known. The third type of mistakes was substitution (19\%) like than for then or thier instead of their. Transposition was reported the least type of spelling mistakes found in the examples of English-major students' answers, which was $15 \%$; the most frequent example of this type in this study was tow for two.

To explain, the findings of the study are discussed in the following subsections, as shown in Table 1 above.

\subsection{Omission Mistakes}

Omission-based mistakes are made by students when deleting or leave out a letter or more from words as a result of ignorance of the actual word spelling. Students are not able to memorize word spelling as they do not practice writing and/ or they spell as they pronounce words. For example, the following are a few examples of omitting silent sounds:

- $\quad$ rite instead of write

- now- instead of know

- $\quad$ forein- instead of foreign

- wich instead of which

- $\quad$ lisen instead of listen 
In order to deal with this situation, the students are encouraged to practice spelling more, so that they can memorize words with silent sounds quickly, as the more they practice, the better speller they become. Another example of mistake omission is omitting the phoneme /e/ at the end of English words, such as:

- $\quad$ hav- instead of have

- befor instead of before

- $\quad$ hid instead of hide

- $\quad$ language/ langaug instead of language

Further, the mistake based on consonant doubling is another problem faced by students in spelling. For example:

- $\quad$ swiming- instead of swimming

- $\quad$ writting- instead of writing

- $\quad$ begining - instead of beginning

- $\quad$ biger instead of bigger

It can be realized that the findings show that students' spelling mistake are associated with their pronunciation. Therefore, any unpronounced sound is deleted, which is a mistake attributed to the lack of phonological rules, where the students find it difficult for them to understand the correlation between letters and sounds. Such findings are in agreement with Aqel's conclusions (1993), which indicate that omission-based mistake is caused by the divergence of orthography and pronunciation in English. Besides, the interference of the first language (L1) is also found as one of the significant reasons for omission spelling errors, which corresponds to Al-Jarf's findings (2010), which revealed that one of the most common sources in spelling is transferring the spelling system of Arabic language to English, as both languages have entirely different orthographic systems.

\subsection{Insertion Mistakes}

This type of mistake refers to inserting an extra sound in a word. These misspelled words would be due to the lack of knowledge of English language spelling. Insertion mistakes come in the second place, with 28\% (31 mistakes). For instance, students insert /e/ vowel sound where it is not needed, such as (withe) for (with), (knowen) instead of (known), and (frome) for (from). Further, some students keep /e/ sound when adding -ing to a verb, such as (haveing) instead of (having), (takeing) instead of (taking) and (writeing) instead of (writing) for these verbs (use, take, leave). Insertion of $/ \mathrm{t} /$ is also another type of mistake made by the students, such as (reatch) instead of (reach), (mutch) instead of (much) and (luntch) instead of (lunch). This finding is asserted by Albalawi (2016), where the reason behind these mistakes is due to students' weakness in spelling. More examples made by students majoring in English at WISE are shown in Table 2.

\subsection{Substitution Mistakes}

This type of mistake occurs when one or more sounds are replaced by one or more different sounds. This study indicates that substitution mistakes have a high rate among other spelling mistakes. Having analyzed the substitution mistakes of the students in spelling, it was discovered that the major spelling problem is silent sounds, which have no sound-letter correspondence. Below are a few instances of substitution mistakes in spelling:
A. Vowel Substitution Mistakes
(his) instead of (has) or vice versa; (went)- instead of (want); (throw) - instead of (through); (than) instead of (then); (pot) instead (put)

B. Plural form Substitution Mistakes

(Classez) instead of (classes); (vizits) instead of (visit); (friendz) instead of (friends). In these examples, the students substitute /s/ by /z/

\section{Consonants Substitution Mistakes}

(How) instead of (who) or vice versa; (but) instead of (put); (bacic) instead of (basic); (foto) instead of photo;

(jop) instead of (job); (beld) instead of (build); (litter) instead of (letter).

The examples given include the students' substitution of /z/ instead of /s/, /f/ instead /ph/, /b/ instead of /p/, /k/ instead of $/ \mathrm{c} /$ and $/ \mathrm{s} /$ instead of $/ \mathrm{c} /$. These findings show the spelling problems faced by the students in terms of substitution mistakes. This finding is in line with Cook (1999), who reported that the reason behind the vowel 
substitution mistakes made by Arab students is pronunciation.

Table 2. Examples on spelling mistakes made by student of English at WISE

\begin{tabular}{|c|c|c|}
\hline Mistake types & Mistakes & The correct words \\
\hline \multirow{8}{*}{ Omission } & Languag/ languge & Language \\
\hline & Befor/ & Before \\
\hline & Wich/ & Which \\
\hline & Frind & Friend \\
\hline & Hapy & Нарру \\
\hline & Now & Know \\
\hline & Writen & Written \\
\hline & Voicd & Voiced \\
\hline \multirow{7}{*}{ Insertion } & Knowen & Known \\
\hline & Withe & With \\
\hline & Pepol & People \\
\hline & Writting & Writing \\
\hline & Beautifull & Beautiful \\
\hline & Frome & From \\
\hline & Having & Having \\
\hline \multirow{7}{*}{ Substitution } & Bitter & Better \\
\hline & Jop & Job \\
\hline & Their & There \\
\hline & Than & Then \\
\hline & But & Put \\
\hline & Beld & Build \\
\hline & How & Who \\
\hline \multirow{6}{*}{ Transposition } & Thier & Their \\
\hline & Tow & Two \\
\hline & Frind & Friend \\
\hline & Three & There \\
\hline & Bigin & Begin \\
\hline & Well & Will \\
\hline
\end{tabular}

In addition, this study agrees with a study conducted by Aqel (1993) that the mistake substitution type is because of the divergence between English pronunciation and its writing system. This inclination is strengthened due to the Arabic system effect where the pattern of spelling follows the pattern of pronunciation. According to Khuwaileh and Al-Shoumali (2000), "students' mispronunciation, lack of awareness and regular spelling patterns" are considered as reasons behind most of the mistakes made by students in spelling (Othman, 2018).

\subsection{Transposition Mistakes}

This type of mistake includes mistakes made as a result of mis-ordering the sounds of English. Transportation mistakes in this study were shown to come in the fourth place, with a percentage of $15 \%$ (15 mistakes). The study reveals that transposition is one of the spelling problems encountered by Jordanian students. For example, mis-ordering the vowels occurs in words like (freind) instead of (friend) (thier) instead of (their). These transportation mistakes are because of lacking competence and the correct perception of the right form or rule, in 
addition to the little exposure to the English language.

The present study indicates that the major causes of mistakes in spelling are due to the fact that English language and Arabic language have a totally different orthographic approach. Besides, Arabic uses regular spelling rules, which are in agreement with its pronunciation, whereas English uses a completely different system. In addition, the findings of this study are in accordance with the results of Alhaisoni et al. (2015) in analyzing spelling substitution errors, where they claim that a strong relationship exists between the articulations and the spelling of words.

\section{Conclusion}

The purpose of this paper is to examine the most typical mistakes in spelling made by Jordanian students who study English at the WISE University. Generally speaking, the process of learning a second language is challenging, where learners are expected to make mistakes. As a result, students who are concerned with the study of English language ought to consider the fact that Arabic language is entirely different in writing systems from English language. That is to say, the style of writing Arabic language is from right to left, while the style of the English writing is from left to right, which confuses students. Furthermore, one of the differences between Arabic language and English language is that Arabic is a phonetic language, whereas English is not. Consequently, the findings of the study reveal that the reasons behind making mistakes by the students of English at WISE University refer to the interference of students' mother tongue and lack of concentration when answering questions in exams. Besides, the study indicates that many students encounter some spelling problems attributed to the lack of practice of English writing skills. Thus, the best solution for such a problem is to practice more, as the more they practice writing, the better spellers they will be.

\section{References}

AbiSamra, N. (2003). An Analysis of Errors in Arabic Speakers' English Writing. In K. Mourtaga (Ed.), Investigating writing problems among Palestinian students studying English as a foreign language (Unpublished doctoral dissertation).

Al- Harrasi, S. (2012). The Most Common Spelling Errors among Omani Learners. AWEJ, 3(2), 96.

Albalawi, F. S. (2016). Analytical Study of the Most Common Spelling Errors Among Saudi Female Learners of English: Causes and Remedies. Asian Journal of Educational Research, 4(3).

Alhaisoni, E. et al. (2015). Analysis of Spelling Errors of Saudi Beginner Learners of English Enrolled in an Intensive English Language Program. English Language Teaching, 8(3). https://doi.org/10.5539/elt.v8n3p185

Al-Jarf, R. (1999). Listening-spelling strategies of freshmen students. TESOL Arabia.

Al-Jarf, R. (2010). Spelling error corpora in EFL. Sino-US English Teaching, 7(1), 6-15.

Al-Saudi, J. (2013). Error Analysis and Spelling Mistakes of EFL Learners at Tafila Technical University: A Case Study. Frontiers of Language and Teaching, 4, 99-107.

Al-Taani, M. (2006). An investigation of spelling errors found in written composition of Second and third secondary students in the United Arab Emirates (Unpublished Doctoral Thesis). Sudan University science and technology.

Altamimi, D., \& Rashid, R. A. (2019). Spelling Problems and Causes among Saudi English Language Undergraduates. Arab World English Journal, 10(3) 178-191. https://dx.doi.org/10.24093/awej/vol10no3.12

Al-Zuoud, K., \& Kabilan, M. (2013). Investigating Jordanian EFL Students' Spelling Errors at Tertiary Level. International Journal of Linguistics, 5(3), 164-176. https://doi.org/10.5296/ijl.v5i3.3932

Aqel, F. (1993). Grammatical and spelling errors among Palestinian students learning English. Mansoura Faculty of Education Journal, (22), 1-12.

Azzam, R. (1993). The nature of Arabic reading and spelling errors of young children. Reading and writing: An Interdisciplinary Journal, 5, 355-385. https://doi.org/10.1007/BF01043112oi:10.1007/BF01043112

Benyo, A. F. (2014). English Spelling Problems among Students at the University of Dongola, Sudan. International Research Journal. Educational Research, 5(9).

Cook, V. (1999). Teaching spelling. Retrieved February 10, 2013, from http://homepage.ntlworld.com/vivian.c/ Writings/index.htm

Corder, S. (1967). The significance of learners' error. Interlanguage, international review of Applied Linguistics. 
https://doi.org/10.1515/iral.1967.5.1-4.161

Fagerberg, I. (2006). English spelling in Swedish secondary schools: Students' attitudes and Performance [online]. Karlstads University Press. http://kau.divaportal.org/smash/get/diva2.../FULLTEXT01.pdf

Gass, S., \& Selinker, L. (1984). Language transfer in language learning. Rowley, MA: Newbury House.

Glenn, P., \& Hurley, S. (1993). Preventing spelling disabilities. Child Language Teaching and Therapy, 8(3), 1-12. https://doi.org/10.1177/026565909300900101

Hamed, M. (2016). A Study of the Spelling Errors committed by Students of English in Saudi Arabia: Exploration and Remedial Measures. Advances in Language and Literary Studies, 7(1), 203. https://doi.org/10.7575/aiac.alls.v.7n.1p.203

Hildreth, G. (1962). Teaching spelling: A guide to basic principles and practices. New York: Holt, Rinehart and Winston, inc.

Hismanoglu, M., \& Hismanoglu, S. (2010). Language teachers' preferences of pronunciation teaching techniques: Traditional or modern? Procedia-Social and Behavioral Sciences, 2(2), 983-989. https://doi.org/10.1016/j.sbspro.2010.03.138

Khuwaileh, A. A., \& Al Shoumali, A. (2000). Writing Errors: A Study of the Writing Ability of Arab Learners of Academic English and Arabic at University. Language Culture and Curriculum, 13(2), 174-183. https://doi.org/10.1080/07908310008666597

Othman, A. Kh. A. (2018). An Investigation of the Most Common Spelling Errors in English Writing Committed by English-Major Male Students: At the University of Tabuk. Journal of Education and Practice, 9(1).

Ryan, A., \& Paul, M. (1991). The Case of the Invisible Vowels: Arabic Speakers Reading English Words. Reading in a Foreign Language, 7, 531-540.

Taha, H. (2013). Reading and spelling in Arabic: Linguistic and orthographic complexity. Theory and Practice in Language Studies, 3, 721-727. https://doi.org/10.4304/tpls.3.5.721-727

Wachowicz, K. A., \& Scott, B. (1999). Software that Listens: It's not a Question of Whether, It's a Question of How. CALICO Journal, 16(3), 253-276.

\section{Copyrights}

Copyright for this article is retained by the author(s), with first publication rights granted to the journal.

This is an open-access article distributed under the terms and conditions of the Creative Commons Attribution license (http://creativecommons.org/licenses/by/4.0/). 